\title{
Tick mitochondrial genomes: structural characteristics and phylogenetic implications
}

Tianhong Wang, Shiqi Zhang, Tingwei Pei, Zhijun Yu* and Jingze Liu*

\begin{abstract}
Ticks are obligate blood-sucking arachnid ectoparasites from the order Acarina, and many are notorious as vectors of a wide variety of zoonotic pathogens. However, the systematics of ticks in several genera is still controversial. The mitochondrial genome (mt-genome) has been widely used in arthropod phylogeny, molecular evolution and population genetics. With the development of sequencing technologies, an increasing number of tick mt-genomes have been sequenced and annotated. To date, 63 complete tick mt-genomes are available in the NCBI database, and these genomes have become an increasingly important genetic resource and source of molecular markers in phylogenetic studies of ticks in recent years. The present review summarizes all available complete mt-genomes of ticks in the NCBI database and analyses their characteristics, including structure, base composition and gene arrangement. Furthermore, a phylogenetic tree was constructed using mitochondrial protein-coding genes (PCGs) and ribosomal RNA (rRNA) genes from ticks. The results will provide important clues for deciphering new tick mt-genomes and establish a foundation for subsequent taxonomic research.
\end{abstract}

Keywords: Ticks, Mitochondrial genome (mt-genome), Gene structure, Phylogeny

\section{Background}

Ticks are obligate blood-sucking arachnid ectoparasites that can feed on a wide range of vertebrates, including mammals, birds and reptiles [1, 2]. Ticks are well-known zoonotic pathogen vectors, and tick-borne diseases (TBDs) are increasingly threatening animal and human health, thereby causing great economic damage $[3,4]$. Many important tick-borne pathogens have been characterized from ticks in recent years, including Anaplasma bovis, Babesia ovata, Rickettsia japonica, Chlamydiaceae bacteria and severe fever with thrombocytopenia syndrome virus (SFTSV), which have attracted increasing attention in the field of public health [5-9]. Recently, a newly segmented virus with a febrile illness similar in its clinical manifestation to tick-borne encephalitis virus (TBEV) was discovered, which was designated as Alongshan virus (ALSV) and confirmed in 86 patients from several provinces in China [10]. Globally, the annual

*Correspondence: yuzhijun@hebtu.edu.cn; liujingze@hebtu.edu.cn Hebei Key Laboratory of Animal Physiology, Biochemistry and Molecular Biology, College of Life Sciences, Hebei Normal University,

Shijiazhuang 050024, China financial losses due to ticks and TBDs are in the billions of dollars [3,11]. A total of 896 tick species have been described worldwide in three families: Ixodidae (hard ticks, 702 species), Argasidae (soft ticks, 193 species) and Nuttalliellidae (1 species) [12-14]. Hard ticks possess a sclerotized scutum in all life stages except eggs, have an apically located gnathostoma, usually feed for several days and ingest a large amount of blood $[15,16]$. Soft ticks have no sclerotized scutum and mouthparts located anteroventrally. The ticks usually feed and expand the body within minutes to hours [17]. Nuttalliella namaqua is the unique species in the family Nuttalliellidae, and it displays many characteristics associated with hard and soft ticks and can engorge as rapidly as soft ticks [18]. The differences in life history, behaviour, and morphological characteristics are useful for the discrimination of soft ticks and hard ticks, but there are still numerous difficulties among the interspecies taxonomic characterization and geographical origin of ticks, especially for soft ticks [19]. Therefore, the increasing number of characterized mt-genomes has shown considerable potential in tick phylogeny, molecular evolution and population genetics. 
The mt-genome is characterized by low molecular weight, high copy quantity and genetic conservation. The mt-genome has been widely used in molecular evolution, phylogeny and genealogy in recent years [20-22]. Similar to other arthropods, the tick mt-genome has a circular, double-stranded DNA structure with a length of 14-16 $\mathrm{kb}$ and a total of 37 genes, including 13 protein-coding genes, 22 transfer RNA genes (tRNAs) and 2 rRNA genes [20, 23]. With the development of next-generation sequencing (NGS) technology, increasing numbers of complete mt-genomes have been sequenced and annotated from various tick species [24]. The complete mtgenome sequences are necessary for advances in areas that are crucial for TBDs study and control [24]. To date, 63 complete tick mt-genomes are available in the NCBI database, and these genomes have become an increasingly important genetic resource and source of molecular markers in phylogenetic studies of ticks in recent years $[19,25]$. Hence, in the present study, we used the MITOS online software (http://mitos.bioinf.uni-leipzig.de/index .py/) to annotate the complete mt-genomes of ticks and compare their characteristics, including structure, base composition and gene arrangement. Furthermore, a phylogenetic tree was constructed using PCGs and rRNA genes from ticks. The results will provide important clues for deciphering new tick mt-genomes and provide insights for subsequent taxonomic research.

\section{Present state of research on tick mt-genomes}

The first mt-genomes of ticks (Ixodes hexagonus and Rhipicephalus sanguineus) were reported by Black et al. [26] in 1998. As of May 2019, 63 complete tick mt-genomes have been deposited in the NCBI database. Most tick mtgenomes were published in this decade, and are from 3 families and 15 genera, including 35 species in the family Ixodidae: Ixodes (7 species); Amblyomma (7 species); Rhipicephalus (5 species); Rhipicentor (1 species); Dermacentor (4 species); Bothriocroton (2 species); Haemaphysalis (8 species); and Hyalomma (1 species) [26-41]; 27 species in the family Argasidae: Argas (8 species); Antricola (1 species); Carios (2 species); Ornithodoros (14 species); Otobius (1 species); and Nothoaspis (1 species) [19, 27, 42-44]; and 1 Nuttalliella species in family Nuttalliellidae [44] (Table 1). In recent years, phylogenetic studies based on mt-genome sequences have been effectively carried out for many tick species [21, 28-30, $36,40]$. These achievements are also essential for understanding the genetic differentiation and phylogeny of ticks [31-34]. However, the genera Anomalohimalaya, Compluriscutula, Margaropus and Nosomma still lack complete mt-genome information, and most species were sampled in a limited geographical area [45]. Complete mt-genome sequences have only been obtained for approximately $7 \%(63 / 896)$ of the tick species, and the general characteristics of most tick mt-genomes remain to be determined.

\section{Basic features of tick mt-genomes}

The length of the mt-genomes of ticks average 14,633 $\mathrm{bp}$, with the longest reaching 15,227 bp (Ixodes tasmani) and the smallest measuring only 14,307 bp (Argas boueti) (Table 2). Generally, the length of the mt-genomes from hard ticks is slightly longer than that of soft ticks $(14,796$ and $14,429 \mathrm{bp}$, respectively). The length differences of the mt-genomes between ticks may be influenced by gene rearrangement and the length of the non-coding regions (NCRs) [46, 47]. MITOS online analysis showed no gene deletion or duplication in tick mt-genomes, which contain 13 PCGs, 2 rRNA genes and 22 tRNA genes. Among the 13 PCGs, 9 PCGs (nad2, cox1, cox2, atp8, atp6, cox3, $n a d 3, n a d 6, c y t b)$ are located in the majority strand (J strand) and 4 PCGs (nad5, nad4, nad4L, nad1) are located in the minority strand ( $\mathrm{N}$ strand).

Metazoan mt-genomes usually have a higher adeninethymine (AT) base content [22, 32, 42]. Analysis of base usage in tick mt-genomes showed that the AT content ranged from $80.45 \%$ (Amblyomma elaphense) to $65.23 \%$ (Ornithodoros savignyi) with an average content of $75.51 \%$ (Table 2). The difference in base usage within the family is generally small $[48,49]$, but the largest difference in AT content between soft and hard ticks reached $15.22 \%$. This phenomenon may be attributed to the lower AT content in Ornithodoros species, which is $71.65 \%$ on average and is considerably lower than the average AT content of ticks. It is possible that the difference in AT content is related to the size of the NCRs, the repeat sequences and the complexity of the gene structure [5052]. Additionally, the different living environments and survival strategies of soft and hard ticks influence base usage [53].

The base skew of tick mt-genomes is unique. In general, AT-skew is positive and guanine-cytosine (GC) skew is negative in the metazoan mt-genomes [54, 55], whereas the AT-skew of soft and hard ticks is different. In soft ticks, the AT-skew is positive. In hard ticks, the positive AT-skew is only observed in I. hexagonus and Ixodes uriae, whereas in other hard ticks, the AT skew is negative. In both soft and hard ticks, the average AT-skew is 0.0504 and -0.0187 , respectively, and the average GCskew is -0.3532 and -0.1701 , respectively; notably the difference in AT-skew is smaller than that in GC-skew (Table 2).

\section{Protein-coding genes and codon usage}

The PCGs in mt-genomes encode several subunits: NADH dehydrogenase subunit, cytochrome $c$ oxidase 
Table 1 The available tick complete mitochondrial genomes in GenBank

\begin{tabular}{|c|c|c|c|c|}
\hline Family & Genus & Species & GenBank ID & Reference \\
\hline Nuttalliellidae & Nuttalliella & N. namaqua & JQ665719 & Mans et al. [44] \\
\hline \multirow[t]{27}{*}{ Argasidae } & \multirow[t]{8}{*}{ Argas } & A. africolumbae & KJ133580 & Mans et al. [44] \\
\hline & & A. boueti & KR907234 & Mans et al. [Unpublished] ${ }^{\mathrm{a}}$ \\
\hline & & A. brumpti & KR907226 & Mans et al. [Unpublished] \\
\hline & & A. lagenoplastis & KC769587 & Burger et al. [27] \\
\hline & & A. miniatus & KC769590 & Burger et al. [27] \\
\hline & & A. persicus & KJ133581 & Mans et al. [Unpublished] \\
\hline & & A. striatus & KJ133583 & Mans et al. [Unpublished] \\
\hline & & A. walkerae & KJ133585 & Mans et al. [Unpublished] \\
\hline & Antricola & A. mexicanus & KC769591 & Burger et al. [27] \\
\hline & \multirow[t]{2}{*}{ Carios } & C. capensis & AB075953 & Fukunaga et al. [Unpublished] \\
\hline & & C. faini & KJ133589 & Mans et al. [Unpublished] \\
\hline & Nothoaspis & N. amazoniensis & KX712088 & Lima et al. [Unpublished] \\
\hline & \multirow[t]{14}{*}{ Ornithodoros } & O. brasiliensis & KC769593 & Burger et al. [27] \\
\hline & & O. compactus & KJ133590 & Mans et al. [Unpublished] \\
\hline & & O. coriaceus & MG593161 & Mans et al. [Unpublished] \\
\hline & & O. costalis & KJ133591 & Mans et al. [Unpublished] \\
\hline & & O. hermsi & MF818032 & Mans et al. [Unpublished] \\
\hline & & O. moubata & AB073679 & Fukunaga et al. [43] \\
\hline & & O. parkeri & MF818029 & Mans et al. [Unpublished] \\
\hline & & O. porcinus & AB105451 & Mitani et al. [42] \\
\hline & & O. rostratus & KC769592 & Burger et al. [27] \\
\hline & & O. savignyi & KJ133604 & Mans et al. [Unpublished] \\
\hline & & O. sonrai & MF818026 & Mans et al. [Unpublished] \\
\hline & & O. tholozani & MF818023 & Mans et al. [Unpublished] \\
\hline & & O. turicata & MF818021 & Mans et al. [Unpublished] \\
\hline & & O.zumpti & KR907257 & Mans et al. [Unpublished] \\
\hline & Otobius & O. megnini & KC769589 & Burger et al. [27] \\
\hline \multirow[t]{21}{*}{ |xodidae } & \multirow[t]{7}{*}{ Ixodes } & I. hexagonus & AF081828 & Black et al. [26] \\
\hline & & I. holocyclus & AB075955 & Shao et al. [41] \\
\hline & & I. pavlovskyi & KJ000060 & Mikryukova et al. [Unpublished] \\
\hline & & I. persulcatus & KU935457 & Sui et al. [40] \\
\hline & & I. ricinus & JN248424 & Montagna et al. [39] \\
\hline & & I. tasmani & MH043269 & Burnard et al. [25] \\
\hline & & I. uriae & AB087746 & Shao et al. [37] \\
\hline & \multirow[t]{7}{*}{ Amblyomma } & A. americanum & KP941755 & Williams-Newkirk et al. [36] \\
\hline & & A. cajennense & $J X 573118$ & Burger et al. [29] \\
\hline & & A. elaphense & JN863729 & Burger et al. [29] \\
\hline & & A. fimbriatum & JN863730 & Burger et al. [28] \\
\hline & & A. sculptum & KX622791 & Lima et al. [31] \\
\hline & & A. sphenodonti & JN863731 & Burger et al. [29] \\
\hline & & A. triguttatum & AB113317 & Fukunaga et al. [Unpublished] \\
\hline & \multirow[t]{5}{*}{ Rhipicephalus } & R. australis & KC503255 & Burger et al. [27] \\
\hline & & R. geigyi & KC503263 & Burger et al. [27] \\
\hline & & R. microplus & KC503261 & Burger et al. [30] \\
\hline & & R. sanguineus & $J X 416325$ & Liu et al. [32] \\
\hline & & R. turanicus & KY996841 & Li et al. [Unpublished] \\
\hline & Rhipicentor & R. nuttalli & MF818020 & Mans et al. [Unpublished] \\
\hline & Dermacentor & D. verestianus & MG986896 & Yu et al. [35] \\
\hline
\end{tabular}


Table 1 (continued)

\begin{tabular}{|c|c|c|c|c|}
\hline Family & Genus & Species & GenBank ID & Reference \\
\hline & & D. nitens & KC503258 & Burger et al. [27] \\
\hline & & D. nuttalli & KT764942 & Guo et al. [33] \\
\hline & & D. silvarum & KP258209 & Chang et al. [Unpublished] \\
\hline & \multirow[t]{2}{*}{ Bothriocroton } & B. concolor & JN863727 & Burger et al. [28] \\
\hline & & B. undatum & JN863728 & Burger et al. [28] \\
\hline & \multirow[t]{8}{*}{ Haemaphysalis } & H. bancrofti & MH043268 & Burnard et al. [25] \\
\hline & & H. concinna & KY364906 & Fu et al. [38] \\
\hline & & H. flava & AB075954 & Shao et al. [41] \\
\hline & & H. formosensis & JX573135 & Burger et al. [29] \\
\hline & & H. hystricis & MH510034 & Tian et al. [Unpublished] \\
\hline & & H. japonica & MG253031 & Fu et al. [Unpublished] \\
\hline & & H. longicornis & MG450553 & Geng et al. [Unpublished] \\
\hline & & H. parva & $J \times 573136$ & Burger et al. [29] \\
\hline & Hyalomma & H. asiaticum & MF101817 & Liu et al. [34] \\
\hline
\end{tabular}

a Unpublished here refers to the sequences deposited into GenBank only without paper published

subunit, ATPase subunit and cytochrome $b$, which are mainly involved in the oxidative phosphorylation of cells [56]. The average length of mitochondrial PCGs in soft and hard ticks is 10,866 and $10,819 \mathrm{bp}$, respectively (Table 2). The AT content in PCGs of the soft ticks $(71.81 \%)$ and hard ticks $(77.36 \%)$ is also lower than that in the complete mt-genome level. The lowest AT content in PCGs is in Rhipicephalus geigyi (63.59\%) and the highest is in Ornithodoros savignyi (80.47\%). The base skew in PCGs of ticks is negative, and the skewness characteristics are similar in both soft and hard ticks. No obvious differences have been observed in different genera of ticks, and the level of AT-skew is higher than that of the GC-skew. The mitochondrial PCGs are involved in oxidative phosphorylation and energy production; therefore, the structure is relatively conserved, and the difference in base usage is lower than that of the whole genome. In addition, the higher AT content of tick mt-genomes may be influenced by gene sequences, with there being only a $0.11-1.64 \%$ gap between the AT content of PCGs and the whole mt-genome (Table 2).

Similarly to insects, ticks usually adopt the "ATN"type codon as the initial codon in PCGs $[31-34,57]$. Other codons, including some special initiation codons, can be edited to conventional start codons during transcription [58-60], which may help reduce the gene spacer region and overlapping region and not affect the normal translation of proteins [61]. The termination codons of ticks are mainly TAA and TAG $[31,34]$ and sometimes use "T" or "TA", which may be converted into a complete termination codon by polyadenylation after translation $[62,63]$.

\section{Transfer RNA and ribosomal RNA genes}

The mitochondrial tRNA gene length in ticks ranges from 50 to $90 \mathrm{bp}$, and most tRNA genes have a complete cloverleaf structure, including four principal structures: amino acid acceptor (AA) arm; TYC (T) arm; anticodon (AC) arm; and dihydrouridine (DHU) arm [64]. No DHU arm structure exists in trnS1 of the tick mt-genomes; a similar phenomenon is also observed in insects $[20,65$, 66]. The distance from the anti-codon to the CCA terminus is hence maintained through the inverted L structure, which helps complete the gene function [67]. Additionally, base mismatches frequently occur in the secondary structure of the tick tRNA genes $[68,69]$. The mismatch types are mainly G-U, U-G and U-U, which are similar to those of other insects $[62,70]$. These mismatches may be related to the evolutionary mutations and may not affect the function of tRNA genes due to being corrected later [71].

The mitochondrial rRNA genes display a complex functional structure with a relatively slow evolution rate; these have long been used as population genetics markers [72]. The tick mt-genomes contain two single copy $12 S$ and $16 S$ rRNA genes. In recent years, the mitochondrial $12 S$ and $16 S$ rRNA genes have been extensively used as genetic targets in phylogenetic research of ticks [27, 36, 73]. Due to gene rearrangement, the position of the rRNA genes shifts in ticks, whereas the gene order and the location in the N strand remain unchanged. Previous reports have shown that the average genetic distance of different tick taxa was still very slight even after tens of million years of evolution. Slow nucleotide variation in rRNA genes may be caused by strict structural and functional limitations [27]. Therefore, to this end, using 


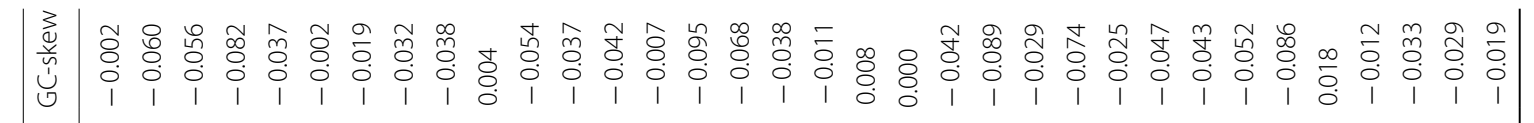

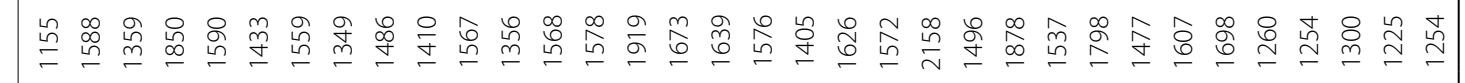

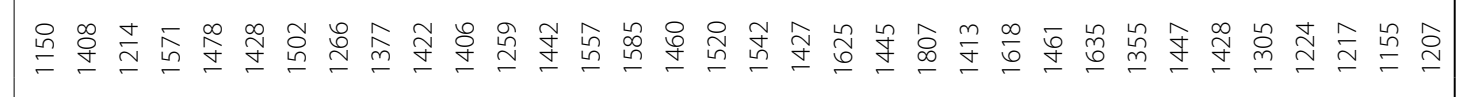

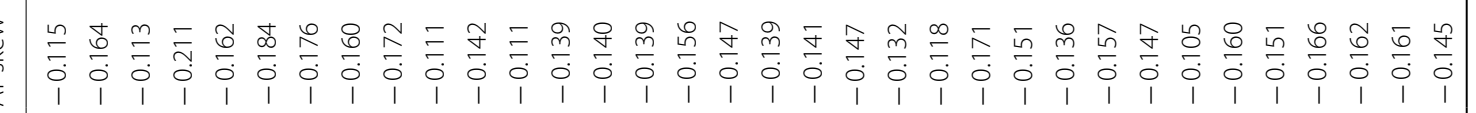

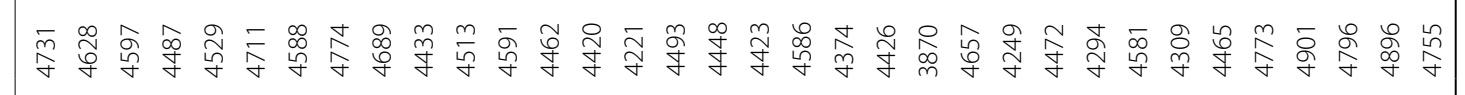

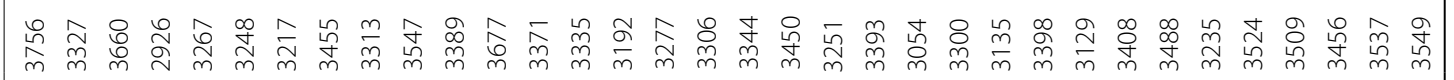

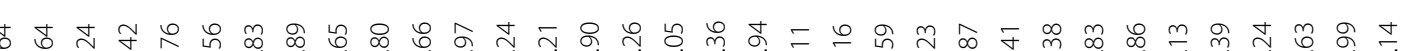

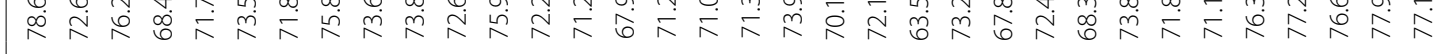

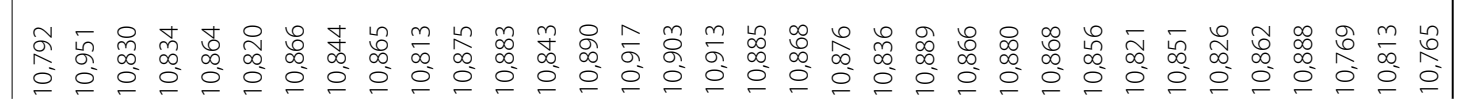

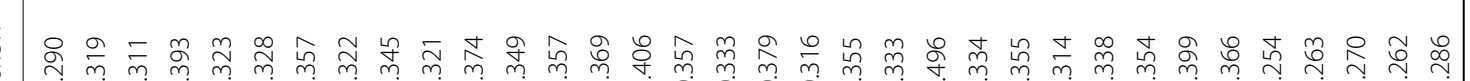

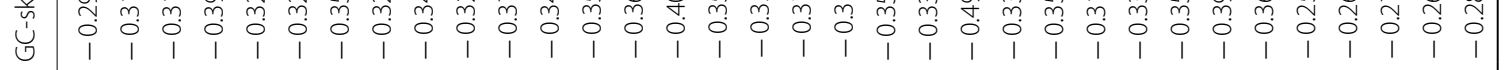

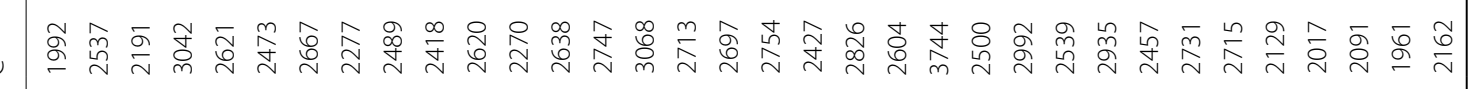

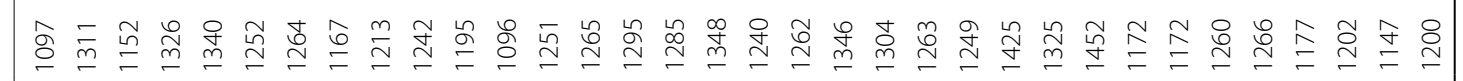

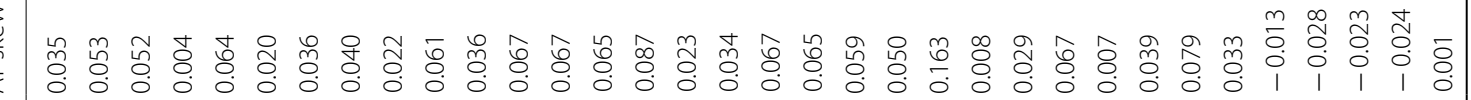

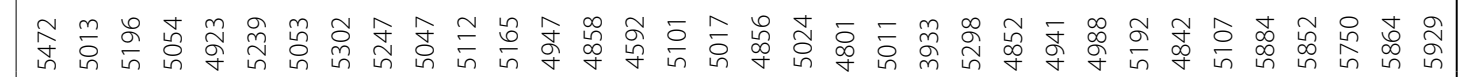

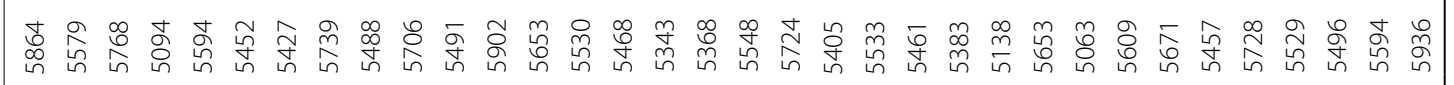
ins

ด

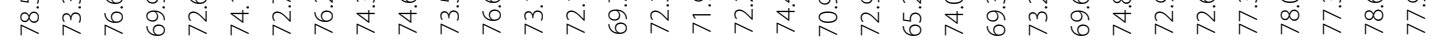

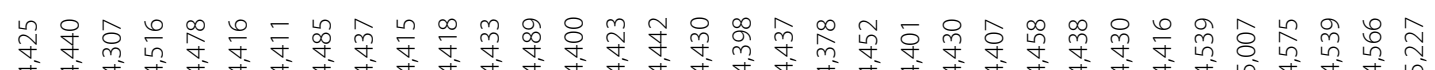

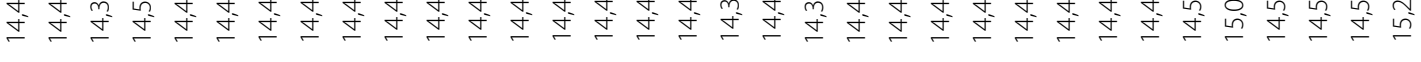




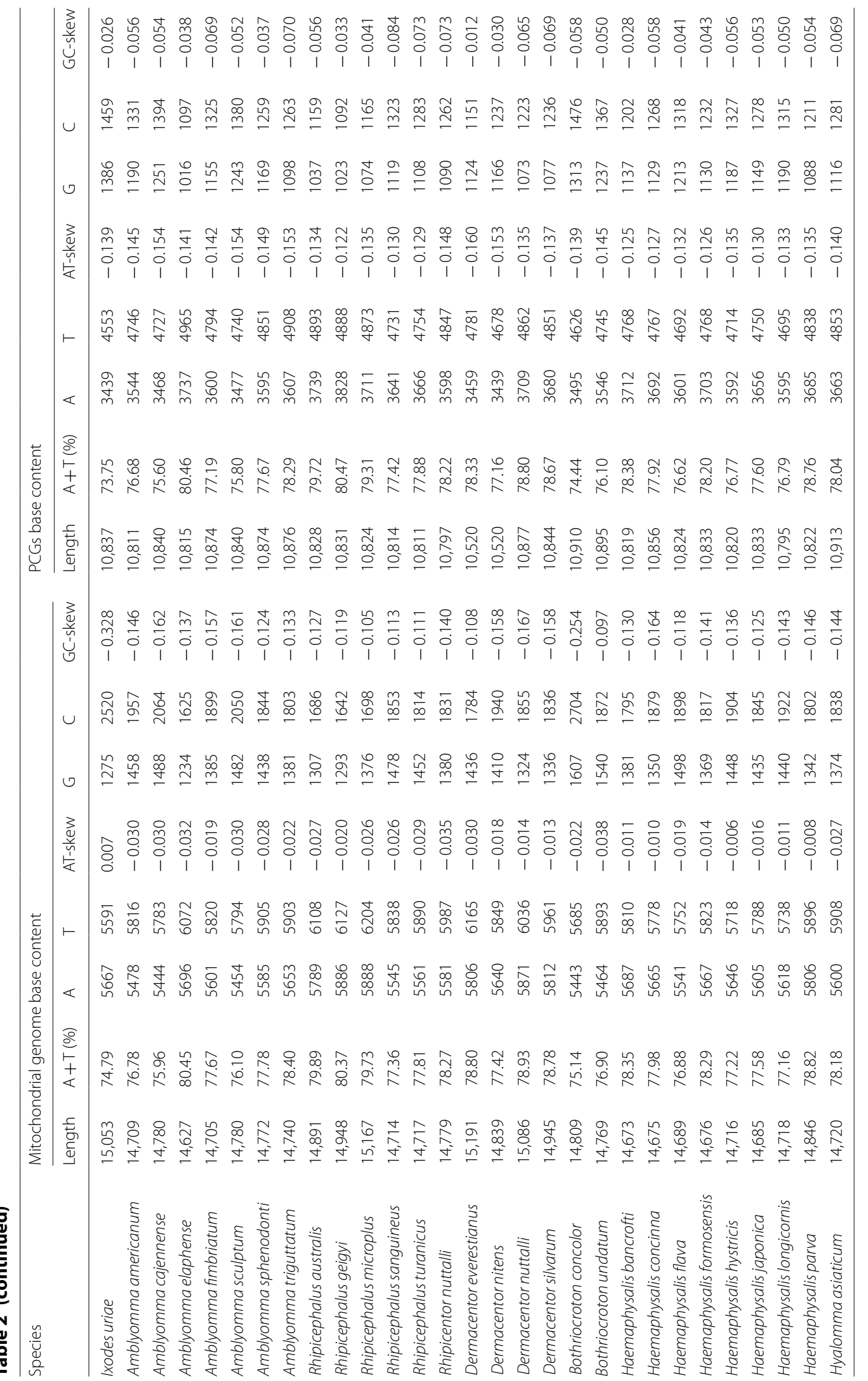


combined PCGs and rRNA genes to reconstruct the phylogenetic relationships and resolve the controversial genealogy of soft ticks may be one of the best methods [19].

\section{Gene rearrangement}

The mt-genomes exhibit higher rearrangement potential, but in general, the gene arrangement most likely occurs at a higher taxonomic level, which can provide insights for systematic classification at higher taxa [74, 75]. There are three types of changes in tRNA gene position: shuffling (local rearrangements), translocation (cross-gene displacement) and inversion (change in the encoding or transcriptional direction) [76]. The rearrangements in the tick mt-genomes are mainly divided into two patterns (Fig. 1). The arrangement of the soft ticks and N. namaqua show more similarity with that in the genus Drosophila [77, 78], which represents the ancestral arrangement in insects. In detail, shuffle (minor rearrangement of the gene) is observed only in the trnL2 gene [48], which is moved from $\operatorname{cox} 1-\operatorname{cox} 2$ to nad1-trnL1 with the coding strand changed from the J strand to the $\mathrm{N}$ strand, whereas other genes remain unchanged. In hard ticks, a major gene rearrangement is observed in a large gene region (trnF-nad5-trnH-nad4-nad4L-trnT-trnP-cytb-trnS2), which is moved from trnE-nad 1 to trnQ-trnM. The major gene rearrangement involves the translocation of three tRNA genes (trnL1, $\operatorname{trnL} 2$ and $\operatorname{trn} C$ ) and the inversion of the $\operatorname{trn} \mathrm{C}$ gene. The patterns in gene rearrangement might be associated with the rate of molecular evolution, and the different rearrangements between soft and hard ticks may have occurred from a very early period $[74,79]$.

\section{Non-coding regions}

In insects, the transcription termination of the mitochondrial NCRs is realized by combining transcription termination factors [80]. In ticks, the mt-genome features a compact structure, which usually contains two conserved site-specific NCRs and several genus-specific conserved NCRs [19, 27, 28, 34, 39]. The larger NCR is located between $r r n S-t r n I$ and is approximately $200-400$ bp long (Table 3). The length of NCR in soft and hard

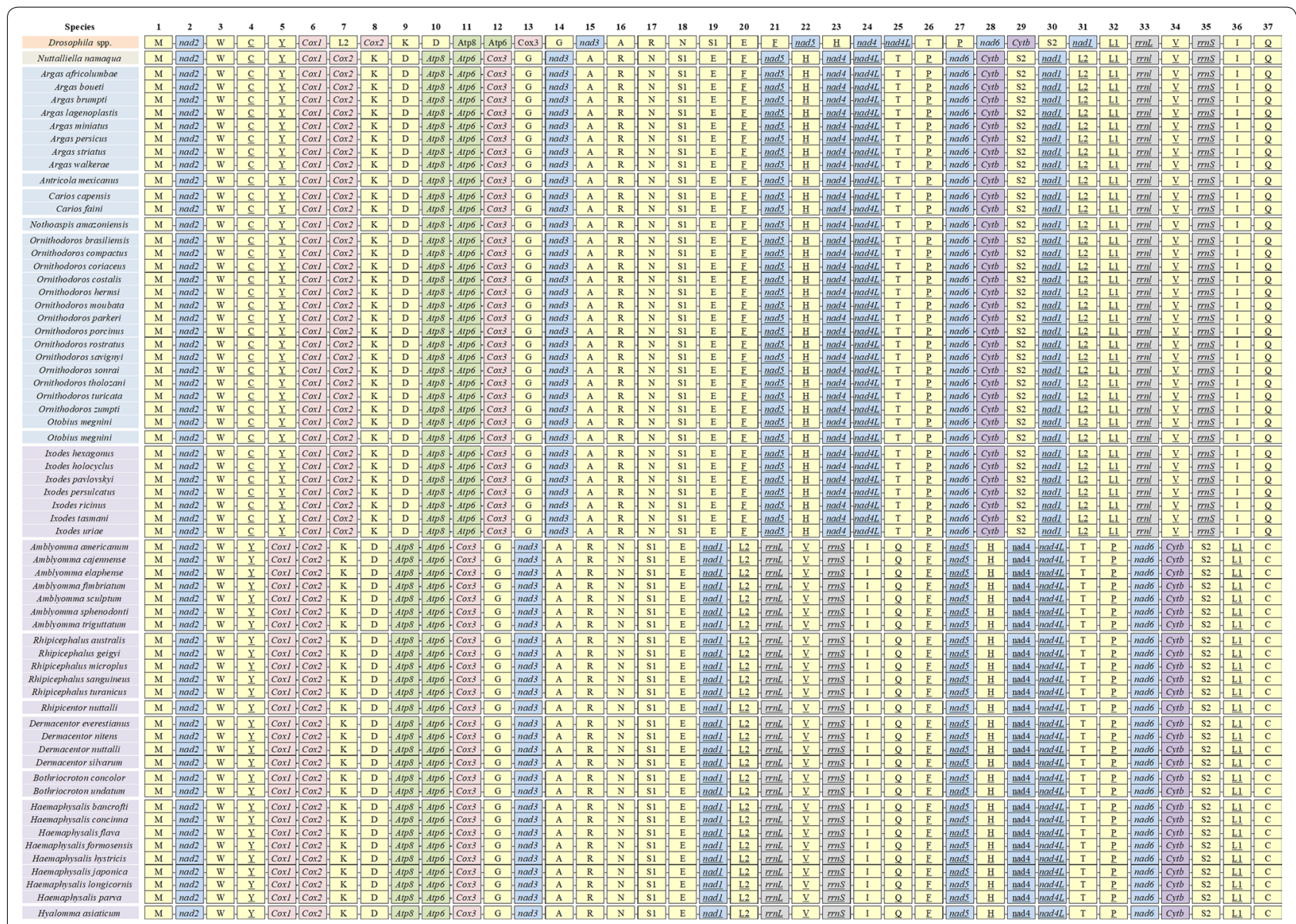

Fig. 1 Gene rearrangement in the tick mitochondrial genomes 
Table 3 Distribution of NCRs in the tick mitochondrial genomes

\begin{tabular}{|c|c|c|c|c|c|c|c|c|c|c|}
\hline \multirow[t]{2}{*}{ Species } & \multicolumn{6}{|c|}{ Conservative noncoding region } & \multicolumn{4}{|c|}{ Nonconservative noncoding region } \\
\hline & Length & Position & Length & Position & Length & Position & Length & Position & Length & Position \\
\hline Nuttalliella namaqua & 182 & $r r n L-t r n V$ & 229 & rrns-trnl & & & 361 & trnF-nad5 & & \\
\hline Argas africolumbae & 185 & $r r n L-t r n V$ & 293 & $r r n S-t r n l$ & & & & & & \\
\hline Argas brumpti & 184 & $r r n L-t r n V$ & 280 & $r r n S-t r n l$ & & & & & & \\
\hline Argas boueti & 553 & $r r n L-t r n V$ & 279 & $r r n S-t r n l$ & & & & & & \\
\hline Argas lagenoplastis & 565 & $r r n L-t r n V$ & 238 & $r r n S-t r n l$ & & & & & & \\
\hline Argas miniatus & 178 & $r r n L-t r n V$ & 273 & $r r n S-t r n l$ & & & & & & \\
\hline Argas persicus & 179 & $r r n L-t r n V$ & 248 & $r r n S-t r n l$ & & & & & & \\
\hline Argas striatus & 182 & $r r n L-t r n V$ & 295 & $r r n S-t r n l$ & & & 112 & nad2-trnW & & \\
\hline Argas walkerae & 177 & $r r n L-\operatorname{trnV}$ & 272 & $r r n S-t r n l$ & & & & & & \\
\hline Antricola mexicanus & 189 & $r r n L-t r n V$ & 264 & $r r n S-t r n l$ & & & 104 & nad2-trnW & & \\
\hline Carios capensis & 177 & $r r n L-t r n V$ & 308 & rrns-trnl & & & & & & \\
\hline Carios faini & 188 & $r r n L-t r n V$ & 259 & $r r n S-t r n l$ & & & & & & \\
\hline Nothoaspis amazoniensis & 186 & $r r n L-t r n V$ & 264 & $r r n S-t r n l$ & & & 124 & trnF-nad5 & & \\
\hline Ornithodoros brasiliensis & 193 & $r r n L-t r n V$ & 294 & rrns-trnl & & & & & & \\
\hline Ornithodoros compactus & 176 & $r r n L-t r n V$ & 267 & rrns-trnl & & & & & & \\
\hline Ornithodoros coriaceus & 189 & $r r n L-t r n V$ & 283 & rrnS-trnl & & & & & & \\
\hline Ornithodoros costalis & 190 & $r r n L-t r n V$ & 254 & $r r n S-t r n l$ & & & & & & \\
\hline Ornithodoros hermsi & 188 & $r r n L-t r n V$ & 269 & $r r n S-t r n l$ & & & & & & \\
\hline Ornithodoros moubata & 176 & $r r n L-t r n V$ & 283 & rrns-trnl & & & & & & \\
\hline Ornithodoros parkeri & 192 & $r r n L-t r n V$ & 257 & $r r n S-t r n l$ & & & & & & \\
\hline Ornithodoros porcinus & 174 & $r r n L-t r n V$ & 265 & rrnS-trnl & & & & & & \\
\hline Ornithodoros tratus & 190 & $r r n L-t r n V$ & 289 & $r r n S-t r n l$ & & & & & & \\
\hline Ornithodoros avignyi & 181 & $r r n L-t r n V$ & 266 & rrns-trnl & & & 125 & trnF-nad5 & & \\
\hline Ornithodoros sonrai & 563 & $r r n L-t r n V$ & 255 & $r r n S-t r n l$ & & & & & & \\
\hline Ornithodoros tholozani & 554 & $r r n L-t r n V$ & 292 & $r r n S-t r n l$ & & & & & & \\
\hline Ornithodoros turicata & 189 & $r r n L-t r n V$ & 286 & rrnS-trnl & & & 122 & nad4-nad4L & & \\
\hline Ornithodoros zumpti & 564 & $r r n L-t r n V$ & 271 & $r r n S-t r n l$ & & & & & & \\
\hline Otobius megnini & 195 & $r r n L-t r n V$ & 290 & $r r n S-t r n l$ & & & & & & \\
\hline Ixodes hexagonus & 189 & $r r n L-t r n V$ & 268 & rrns-trnl & & & & & & \\
\hline Ixodes holocyclus & 335 & $r r n L-t r n V$ & 349 & $r r n S-t r n l$ & 335 & $\operatorname{trn} L 1-\operatorname{trn} C$ & & & & \\
\hline Ixodes pavlovskyi & 193 & $r r n L-t r n V$ & 351 & rrns-trnl & & & & & & \\
\hline Ixodes persulcatus & 183 & $r r n L-t r n V$ & 282 & $r r n S-t r n l$ & & & 122 & $\operatorname{trnH}$-nad4 & & \\
\hline Ixodes ricinus & 197 & $r r n L-t r n V$ & 351 & $r r n S-t r n l$ & & & 107 & nad2-trnW & & \\
\hline Ixodes tasmani & 481 & $r r n L-t r n V$ & 366 & rrnS-trnl & & & 145 & nad4-nad4L & & \\
\hline Ixodes uriae & 354 & $r r n L-t r n V$ & 385 & $r r n S-t r n l$ & 354 & $\operatorname{trn} L 1-\operatorname{trn} C$ & & & & \\
\hline Amblyomma americanum & 169 & $r r n L-t r n V$ & 237 & rrns-trnl & 306 & $\operatorname{trn} L 1-\operatorname{trn} C$ & & & & \\
\hline Amblyomma cajennense & 172 & $r r n L-t r n V$ & 283 & rrns-trnl & 306 & $\operatorname{trn} L 1-\operatorname{trn} C$ & & & & \\
\hline Amblyomma elaphense & 515 & $r r n L-t r n V$ & 238 & rrnS-trnl & 299 & $\operatorname{trn} L 1-\operatorname{trn} C$ & 127 & nad2-trnW & & \\
\hline Amblyomma fimbriatum & 165 & $r r n L-t r n V$ & 230 & $r r n S-t r n l$ & 274 & $\operatorname{trn} L 1-\operatorname{trn} C$ & & & & \\
\hline Amblyomma sculptum & 172 & $r r n L-t r n V$ & 247 & $r r n S-t r n l$ & 306 & $\operatorname{trn} L 1-\operatorname{trn} C$ & & & & \\
\hline Amblyommas phenodonti & 158 & $r r n L-t r n V$ & 297 & rrns-trnl & 328 & $\operatorname{trn} L 1-\operatorname{trn} C$ & & & & \\
\hline Amblyomma triguttatum & 155 & $r r n L-t r n V$ & 264 & $r r n S-t r n l$ & 307 & $\operatorname{trn} L 1-\operatorname{trn} C$ & 123 & nad2-trnW & 185 & trnF-nad5 \\
\hline Rhipicephalus australis & 157 & $r r n L-t r n V$ & 265 & $r r n S-t r n l$ & 305 & $\operatorname{trn} L 1-\operatorname{trn} C$ & & & & \\
\hline Rhipicephalus geigyi & 541 & $r r n L-t r n V$ & 244 & $r r n S-t r n l$ & 303 & $\operatorname{trn} L 1-\operatorname{trn} C$ & 241 & $\operatorname{trn} E-n a d 1$ & & \\
\hline Rhipicephalus microplus & 561 & $r r n L-t r n V$ & 264 & $r r n S-t r n l$ & 307 & $\operatorname{trn} L 1-\operatorname{trn} C$ & 124 & nad2-trnW & & \\
\hline Rhipicephalus sanguineus & 157 & $r r n L-t r n V$ & 233 & rrnS-trnl & 303 & $\operatorname{trn} L 1-\operatorname{trn} C$ & & & & \\
\hline Rhipicephalus turanicus & 159 & $r r n L-t r n V$ & 240 & $r r n S-t r n l$ & 304 & $\operatorname{trn} L 1-\operatorname{trn} C$ & & & & \\
\hline Rhipicentor nuttalli & 157 & $r r n L-t r n V$ & 82 & rrns-trnl & 308 & $\operatorname{trn} L 1-\operatorname{trn} C$ & 285 & $\operatorname{trn} E-n a d 1$ & & \\
\hline
\end{tabular}


Table 3 (continued)

\begin{tabular}{|c|c|c|c|c|c|c|c|c|c|c|}
\hline \multirow[t]{2}{*}{ Species } & \multicolumn{6}{|c|}{ Conservative noncoding region } & \multicolumn{4}{|c|}{ Nonconservative noncoding region } \\
\hline & Length & Position & Length & Position & Length & Position & Length & Position & Length & Position \\
\hline Dermacentor everestianus & 569 & $r r n L-t r n V$ & 292 & rrns-trnl & 306 & $\operatorname{trn} L 1-\operatorname{trn} C$ & 322 & trnE-nad1 & 119 & $\operatorname{trn} Q-\operatorname{trn} F$ \\
\hline Dermacentor nitens & 556 & $r r n L-t r n V$ & 235 & $r r n S-t r n l$ & 307 & $\operatorname{trn} L 1-\operatorname{trn} C$ & 168 & trnE-nad1 & 166 & $\operatorname{trn} Q-\operatorname{trn} F$ \\
\hline Dermacentor nuttalli & 556 & $r r n L-t r n V$ & 235 & $r r n S-t r n l$ & 307 & $\operatorname{trn} L 1-\operatorname{trn} C$ & 168 & trnE-nad1 & & \\
\hline Dermacentor silvarum & 556 & $r r n L-t r n V$ & 232 & rrnS-trnl & 307 & $\operatorname{trn} L 1-\operatorname{trn} C$ & 167 & $\operatorname{trn} E-n a d 1$ & & \\
\hline Bothriocroton concolor & 162 & $r r n L-t r n V$ & 247 & rrns-trnl & 311 & $\operatorname{trn} L 1-\operatorname{trn} C$ & & & & \\
\hline Bothriocroton undatum & 157 & $r r n L-t r n V$ & 230 & rrns-trnl & 310 & $\operatorname{trn} L 1-\operatorname{trn} C$ & 113 & nad4-nad4L & & \\
\hline Haemaphysalis bancrofti & 163 & $r r n L-t r n V$ & 262 & rrns-trnl & 307 & $\operatorname{trn} L 1-\operatorname{trn} C$ & & & & \\
\hline Haemaphysalis concinna & 161 & $r r n L-t r n V$ & 230 & rrnS-trnl & 311 & $\operatorname{trn} L 1-\operatorname{trn} C$ & & & & \\
\hline Haemaphysalis flava & 158 & $r r n L-t r n V$ & 228 & rrns-trnl & 311 & $\operatorname{trn} L 1-\operatorname{trn} C$ & & & & \\
\hline Haemaphysalis formosensis & 160 & $r r n L-t r n V$ & 265 & $r r n S-t r n l$ & 311 & $\operatorname{trn} L 1-\operatorname{trn} C$ & & & & \\
\hline Haemaphysalis hystricis & 162 & $r r n L-t r n V$ & 228 & rrnS-trnl & 309 & $\operatorname{trn} L 1-\operatorname{trn} C$ & & & & \\
\hline Haemaphysalis japonica & 156 & $r r n L-t r n V$ & 229 & rrns-trnl & 310 & $\operatorname{trn} L 1-\operatorname{trn} C$ & & & & \\
\hline Haemaphysalis longicornis & 159 & $r r n L-t r n V$ & 240 & rrns-trnl & 309 & $\operatorname{trn} L 1-\operatorname{trn} C$ & & & & \\
\hline Haemaphysalis parva & 158 & $r r n L-t r n V$ & 252 & rrns-trnl & 318 & $\operatorname{trn} L 1-\operatorname{trn} C$ & 211 & trnE-nad1 & & \\
\hline Hyalomma asiaticum & 160 & $r r n L-t r n V$ & 287 & $r r n S-t r n l$ & 307 & $\operatorname{trn} L 1-\operatorname{trn} C$ & & & & \\
\hline
\end{tabular}

ticks averages 274 and 261 bp, respectively. The longest NCR is observed in species of the genus Ixodes with an average length of $336 \mathrm{bp}$. The shortest NCR is only $82 \mathrm{bp}$ in Rhipicentor nuttalli, and the notably short NCR may be attributed to assembly errors. The other conservative NCRs are located between $r r n L$ and $\operatorname{trn} V$, and the length of this region varies greatly. The shortest is only $155 \mathrm{bp}$ in Amblyomma triguttatum, and the longest reaches 565 bp in Argas lagenoplastis. The difference in the average length between the soft and hard ticks is only 1 bp (251 and $252 \mathrm{bp}$, respectively). The length difference of this type of NCR in ticks is often significant within a genus, except for the genus Haemaphysalis, which shares a similar length of $150 \mathrm{bp}$. In addition to the abovementioned two NCRs, there is another NCR located between trnL1 and $\operatorname{trn} C$ in hard ticks. It is possible that the two related genes (trnL1 and $\operatorname{trn} C$ ) may be involved in gene rearrangement, and hence the NCRs may act as a fragment insertion and play specific roles during gene transcription [81, 82]. Additionally, some ticks also exhibit other NCRs, such as Dermacentor nitens and A. triguttatum, which display five NCRs. These NCRs may play important roles in protecting gene function during gene rearrangement, and there are currently four hypotheses to explain the formation of these particular NCRs [27, 33, $41,74]$.

It is noteworthy that a common marker sequence is found in the NCRs of the tick mt-genomes, which are formed by degeneration during evolution and named the "Tick-box" [39]. This conserved sequence is located at the boundary of two gene rearrangement regions in the tick mt-genomes, which may be affected by the arrangement of mitochondrial genes in ticks [27, 36]. However, this sequence is not discarded during long-term evolution and likely functions as a transcriptional maturation or termination signal. Annotation of these sequences can help identify hidden molecular functions, which is useful for genetic analysis of higher taxa [39].

\section{Mt-genome phylogeny}

The mt-genomes play an important role in the molecular systematics and origin of ticks. In the present study, 13 PCGs and 2 rRNA genes from the MITOS analysis results of all available tick complete mt-genomes were used to construct a phylogenetic tree through the maximum likelihood method (ML) [83]. MEGA v.6.0 for Windows (https://www.megasoftware.net/) was first used for alignment and splicing, and then the IQ-Tree online server (http://iqtree.cibiv.univie.ac.at/) was used for establishment of the phylogenetic tree with 1000 bootstrap replications $[84,85]$. The phylogenetic tree was constructed using the nucleotide sequences $(12,150 \mathrm{bp})$ of 63 tick species. Limulus polyphemus (NC003057) was used as the outgroup and the percentage of the bootstrap support is given at each node.

In soft ticks, some species in Argas and Ornithodoros have previously been phylogenetically analyzed using 10 mitochondrial genes [27]. Recently, several new mtgenomes have become available for the genus Argas including Ar. boueti, Ar. brumpti, Ar. persicus, Ar. striatus and Ar. walkerae, and for the genus Ornithodoros including O. compactus, O. coriaceus, O. costalis, O. hermsi, 
O. parkeri, O. sonrai, O. tholozani, O. turicata and O. zumpti. These were incorporated into the present phylogenetic analysis using 13 PCGs and 2 rRNA genes. Results yielded ambiguous species delimitation and phylogenetic relationships of these two genera (Fig. 2), which are complicated with the existing of monophyly, paraphyly, or polyphyly phenomena. Possibly, the concatenation of present genes with other informative genes help a better phylogenetic resolution. The tick Ar. boueti was clustered within the subfamily Ornithodorinae with a minimum bootstrap of $51 \%$. This clustering may influence the location of other genera, including Antricola, Nothoaspis and Carios. Additionally, the tick Carios faini was clustered first with Antricola mexicanus and Nothoaspis amazoniensis, as well as with $C$. capensis. Subsequently, the incongruence was apparent between phylogenetic configurations and morphological characterizations, which requires further evidential confirmation.

In hard ticks, Rhipicentor nuttalli was clustered with species within the genus Rhipicephalus, which provided corroborative evidence for their close relationship. Although most clades among the hard ticks in different genera showed moderate support and the clustering of the tick lineages were similar to previous studies [25], some particular species including Amblyomma elaphense, Am. spnenodonti and Hylomma asiaticum require total evidence support. The only tick in the family Nuttalliellidae, Nuttalliella namaqua, is the sister group of the family Ixodidae, which is similar to the previous mt-genome phylogenetic analysis [27].

$\mathrm{ML}$ analysis of mitochondrial genes is widely used in the molecular systematics of ticks $[19,29,34]$. Although there were some changes in our results, the phylogenetic branching results were similar to those obtained based on ten PCGs [27]. This finding suggests that the combination of more mitochondrial genes may provide more robust evidence for tick taxonomy. Different mitochondrial genes or sites usually have different evolutionary rates, which may affect the topological structure and lower the support rate of the phylogenetic tree, thereby affecting the reliability of phylogenetic results [86, 87]. When the data matrix is partitioned according to both genes and coding sites, the phylogenetic calculation will be difficult to converge, which prevents phylogenetic analysis using a large number of mitochondrial genes simultaneously [88]. Thus, most studies usually adopt different PCGs or gene loci with proper partition, and the calculation can be optimized by modifying gene loci and selecting appropriate phylogenetic tree methods $[89,90]$. Previous research based on morphological and nuclear rRNA data supported the cladistic results of Klompen et al. $[19,91]$. The results obtained by combining multiple mitochondrial PCGs are partly different from those obtained using nuclear rRNA alone. Although some genera clades may change with the increasing number of mt-genomes, most genera remain clustered in the same clades [31-34] (Fig. 2). Molecular evidence based on the mt-genomes largely does not disagree with the recognized phylogenetic status of many tick species [12]. The description of new species and the characterization of new genetic markers will serve to systematically classify ticks [92].

\section{Perspectives and future directions}

Ticks and mites of the subphylum Chelicerata account for $53 \%$ of parasitic arthropods, which cause substantial losses in agriculture and human health [93]. In recent years, the mt-genomes have shown significant advantages and have been widely used in taxonomic and phylogenetic research $[19,36,94]$. However, challenges still exist in systematic investigations on the tick mt-genomes. The number of available mt-genomes remains limited, as only 63 complete tick mt-genomes are presently available in the NCBI database; the complete mt-genomes of approximately 93\% of tick species remain unexplored. The absence of complete tick mt-genomes, especially for some soft ticks with geographical and taxonomic bias will undoubtedly hinder the reliability of the cladistics (phylogenetic) of the species within subclass Acari, order Ixodida. The different evolution rates of mitochondrial genes may lead to variation in gene length of many species, and different sequences. It should be mentioned that the annotation methods would be also able to affect the sequence assembly $[94,95]$. Furthermore, the mitochondrion is essential for energy metabolism and temperature regulation in metazoans [96]. Previous studies have shown that the mitochondrial genes have significantly different transcriptional activities during the freezing or anoxia adaptation and organism development [97-100]. The differential expression of specific functional genes may attribute to adaptive evolution [101]. Finally, no genes are encoded by the NCRs; therefore, NCRs receive less selection pressure during the process of evolution and are prone to base mutations [102]. NCRs can regulate gene expression and have many multiple tandem repeats and complex structures; hence, NCRs are more difficult to sequence $[18,102]$. The tick mt-genomes are characterized by two typical conserved NCRs, but there are significant differences in the length, number, and location among the different species.

Due to the above challenges, several important directions for future research on the tick mt-genomes were prospected. First, more complete mt-genome sequences, combing with morphological characteristics and nucleus sequences, are required to integrately illuminate the phylogenetic relationships within Ixodida. Secondly, through 


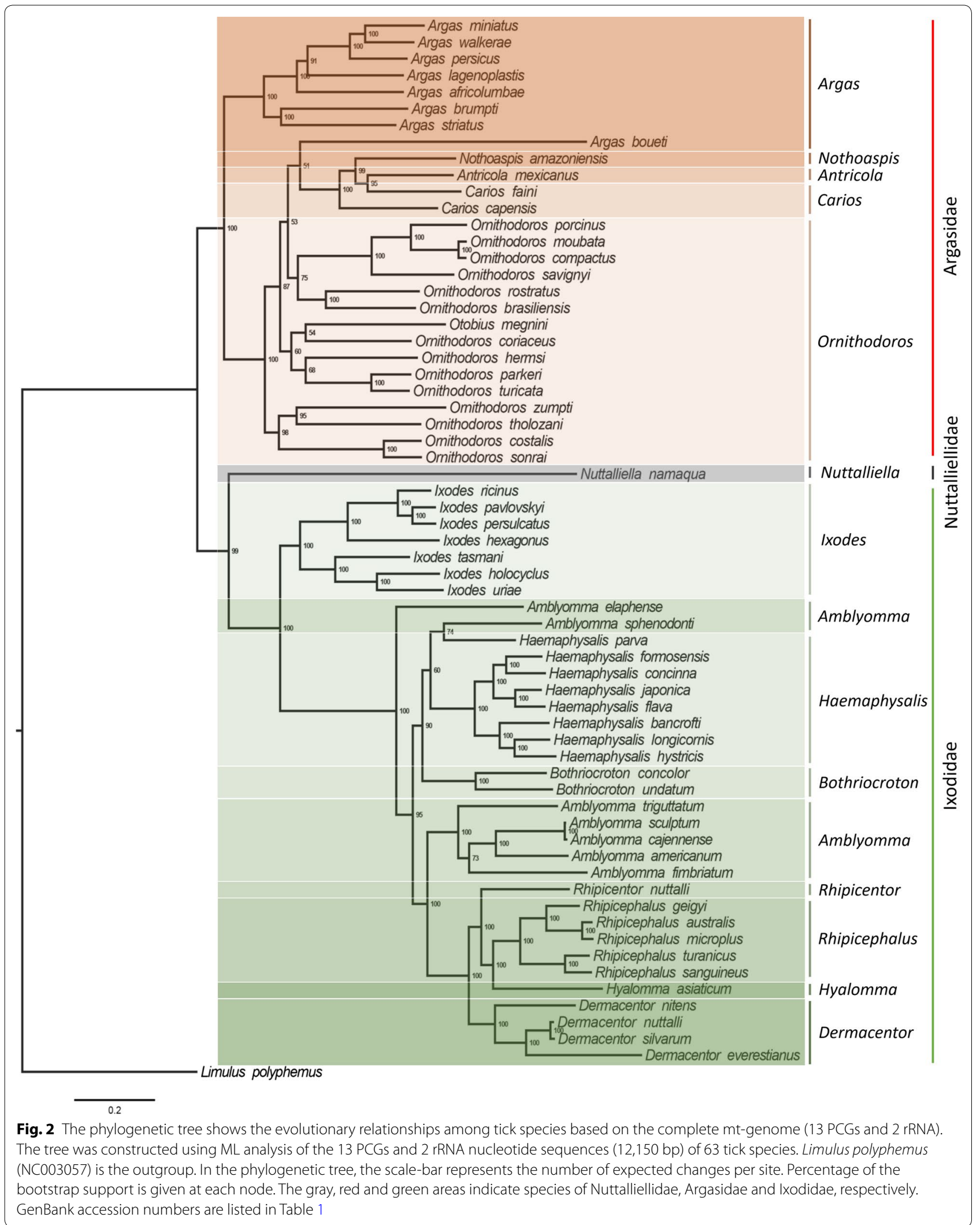


extensive practices, mt-genome annotation methods are constantly improving [94]. However, annotation of a genome is still challenging, as different annotation methods may result in annotation bias or errors [102]. Hence, it is important to use unified annotation methods to help reduce or eliminate incorrect sequencing errors, and more attention should be given to NCRs. Thirdly, the functions and physiological relevance of the tick mitochondrial genes, including mitochondrial transcription, proteomics analysis of mitochondrial proteins, and epigenetic regulation in mitochondria under environmental or physiological stress, warrant further investigation. Finally, it is of considerable practical and theoretical interest to determine whether insecticides and acaricides can act on tick mitochondrial PCGs, which have been previously proved in mites $[103,104]$. This knowledge may provide new molecular biology information to further understand the genetic diversity of ticks, and shed light on novel strategies to control TBDs damage.

\section{Conclusions}

This study summarizes the basic features, including genomic structure, base difference and gene arrangement, of the tick mt-genomes available in the NCBI database. Research on tick mt-genomes has lagged behind that conducted in insects. Fortunately, an increasing number of mt-genomes have been published in recent years, and these have become important molecular markers for the phylogeny of ticks. Our study constructed a phylogenetic tree by maximum likelihood using 13 PCGs and 2 rRNA genes, and the results further supported the phylogenetic status of many tick species. Undoubtedly, the application of polygenic joint analysis and appropriate software will be widely applied in solving the phylogenetic and genetic evolution of diverse taxa of ticks, which will be of profound significance for the rapid identification of tick species.

\begin{abstract}
Abbreviations
TBDs: tick-borne diseases; SFTSV: severe fever with thrombocytopenia syndrome virus; TBEV: tick-borne encephalitis virus; ALSV: Alongshan virus; PCGs: protein-coding genes; tRNA: transfer RNA; rRNA: ribosomal RNA; NGS: nextgeneration sequencing; NCRs: non-coding regions; J strand: majority strand; N strand: minority strand; ML: maximum likelihood.
\end{abstract}

\section{Acknowledgements}

We are very grateful to Dr Abolfazl Masoudi and Yankai Zhang from our laboratory for reviewing the manuscript and providing valuable comments.

\section{Authors' contributions}

$Z Y$ and $J L$ conceived the study. TW drafted the manuscript. JL revised the manuscript. SZ and TP participated in data collection and helped to revise the manuscript. All authors read and approved the final manuscript.

\section{Funding}

This work was supported by the National Natural Science Foundation of China (31672365), the Youth Top Talent Support Program of Hebei Province to ZY, the Natural Science Foundation of Hebei Province (C2019205064), the Natural Science Research Programmes of the Educational Department of Hebei Province (BJ2016032), the Financial Assistance for the Introduction of Overseas Researchers (C20190350) and the Science Foundation of Hebei Normal University (L2018J04).

\section{Availability of data and materials}

Not applicable.

Ethics approval and consent to participate Not applicable.

\section{Consent for publication}

Not applicable.

\section{Competing interests}

The authors declare that they have no competing interests.

Received: 13 May 2019 Accepted: 5 September 2019

Published online: 13 September 2019

\section{References}

1. Kaufman WR. Ticks: physiological aspects with implications for pathogen transmission. Ticks Tick Borne Dis. 2010;1:11-22.

2. Islam MS, You MJ. Expression patterns of host inflammatory cytokine genes during infestation with Haemaphysalis longicornis, a zoonotic vector, in blood-sucking periods. Korean J Parasitol. 2018;56:53-9.

3. Jongejan F, Uilenberg G. The global importance of ticks. Parasitology. 2004;129:S3-14.

4. Ros-Garcã- A, M'Ghirbi Y, Hurtado A, Bouattour A. Prevalence and genetic diversity of piroplasm species in horses and ticks from Tunisia. Infect Genet Evol. 2013;17:33-7.

5. Parola P, Paddock CD, Socolovschi C, Labruna MB, Mediannikov O, Kernif T, et al. Update on tick-borne rickettsioses around the world: a geographic approach. Clin Microbiol Rev. 2013;26:657-702.

6. Takahashi T, Maeda K, Suzuki T, Ishido A. The first identification and retrospective study of severe fever with thrombocytopenia syndrome in Japan. J Infect Dis. 2014;209:816-27.

7. Qin XR, Han FJ, Luo LM, Zhao FM, Han HJ, Zhang ZT, et al. Anaplasma species detected in Haemaphysalis longicornis tick from china. Ticks Tick Borne Dis. 2018;9:840-3.

8. Zhang RL, Huang ZD, Yu GF, Zhang Z. Characterization of microbiota diversity of field-collected Haemaphysalis longicornis (Acari: Ixodidae) with regard to sex and blood meals. J Basic Microbiol. 2019;59:215-23.

9. Burnard D, Weaver H, Gillett A, Loader J, Flanagan C, Polkinghorne A. Novel Chlamydiales genotypes identified in ticks from australian wildlife. Parasit Vectors. 2017;10:46

10. Wang ZD, Wang B, Wei F, Han SZ, Zhang L, Yang ZT, et al. A new segmented virus associated with human febrile illness in China. N Engl J Med. 2019;380:2116-25.

11. Scott JD, Foley JE. Detection of Borrelia americana in the avian coastal tick, Ixodes auritulus (Acari: Ixodidae), collected from a bird captured in Canada. J Anim Sci. 2016;6:207-16.

12. Guglielmone AA, Robbins RG, Apanaskevich DA, Petney TN, Barker SC. The Argasidae, Ixodidae and Nuttalliellidae (Acari: Ixodida) of the world: a list of valid species names. Zootaxa. 2010;2528:1-28.

13. Chen Z, Yang X, Bu F, Yang XH, Yang XL, Liu JZ. Ticks (Acari: Ixodoidea: Argasidae, Ixodidae) of China. Exp Appl Acarol. 2010;51:393-404.

14. Fernandes KK, Bittencourt VP, Roberts DW. Perspectives on the potential of entomopathogenic fungi in biological control of ticks. Exp Parasitol. 2012;130:300-5.

15. McKeever DJ. Bovine immunity-a driver for diversity in Theileria parasites? Trends Parasitol. 2009;25:269-76.

16. Nava S, Beati L, Labruna MB, Cáceres AG, Mangold AJ, Guglielmone AA. Reassessment of the taxonomic status of Amblyomma cajennense, with the description of three new species, Amblyomma tonelliae n. sp. Amblyomma interandinum n. sp. and Amblyomma patinoi n. sp. and reinstatement of Amblyomma mixtum, and Amblyomma sculptum. Ticks Tick Borne Dis. 2014;5:252-76. 
17. Nuttall GHF. Notes on ticks II. Parasitology. 1912;5:50-60.

18. Mans BJ, Neitz AWH. Adaptation of ticks to a blood-feeding environment: evolution from a functional perspective. Insect Biochem Mol Biol. 2004;34:1-17

19. Mans BJ, Featherston J, Kvas M, Pillay KA, Klerk DG, Pienaar R, et al. Argasid and ixodid systematics: implications for soft tick evolution and systematics, with a new argasid species list. Ticks Tick Borne Dis 2019;10:219-40.

20. Cameron SL. Insect mitochondrial genomics: implications for evolution and phylogeny. Annu Rev Entomol. 2014;59:95-117.

21. Simon S, Hadrys H. A comparative analysis of complete mitochondrial genomes among Hexapoda. Mol Phylogenet Evol. 2013;69:393-403.

22. Li K, Liang AP. Hemiptera mitochondrial control region: new sights into the structural organization, phylogenetic utility, and roles of tandem repetitions of the noncoding segment. Int J Mol Sci. 2018;19:1292.

23. Simonsen TJ, Zakharov EV, Djernaes M, Cotton AM, Vane-Wright RI, Sperling FAH. Phylogenetics and divergence times of Papilioninae (Lepidoptera) with special reference to the enigmatic genera Teinopalpus and Meandrusa. Cladistics. 2011;27:113-37.

24. Ramakodi MP, Singh B, Wells JD, Guerrero F, Ray DA. A 454 sequencing approach to dipteran mitochondrial genome research. Genomics. 2015;105:53-60.

25. Burnard D, Shao R. Mitochondrial genome analysis reveals intraspecific variation within Australian hard tick species. Ticks Tick Borne Dis. 2019;10:677-81.

26. Black WC, Roehrdanz RL. Mitochondrial gene order is not conserved in arthropods: prostriate and metastriate tick mitochondrial genomes. Mol Biol Evol. 1998;15:1772-85.

27. Burger TD, Shao R, Labruna MB, Barker SC. Molecular phylogeny of soft ticks (Ixodida: Argasidae) inferred from mitochondrial genome and nuclear rRNA sequences. Ticks Tick Borne Dis. 2014;5:195-207.

28. Burger TD, Shao R, Beati L, Miller H, Barker SC. Phylogenetic analysis of ticks (Acari: Ixodida) using mitochondrial genomes and nuclear rRNA genes indicates that the genus Amblyomma is polyphyletic. Mol Phylogenet Evol. 2012;64:45-55

29. Burger TD, Shao R, Barker SC. Phylogenetic analysis of the mitochondrial genomes and nuclear rRNA genes of ticks reveals a deep phylogenetic structure within the genus Haemaphysalis and further elucidates the polyphyly of the genus Amblyomma with respect to Amblyomma sphenodonti and Amblyomma elaphense. Ticks Tick Borne Dis. 2013;4:265-74.

30. Burger TD, Shao R, Barker SC. Phylogenetic analysis of mitochondrial genome sequences indicates that the cattle tick, Rhipicephalus (Boophilus) microplus, contains a cryptic species. Mol Phylogenet Evol. 2014;76:241-53.

31. de Lima PHC, Barcelos RM, Klein RC, Vidiga PMP, Montandon CE, FabresKlein $\mathrm{MH}$, et al. Sequencing and comparative analysis of the Amblyomma sculptum mitogenome. Vet Parasitol. 2017;247:121-8.

32. Liu GH, Chen F, Chen YZ, Song HQ, Lin RQ, Zhou DH, et al. Complete mitochondrial genome sequence data provides genetic evidence that the brown dog tick, Rhipicephalus sanguineus, (Acari: Ixodidae) represents a species complex. Int J Biol Sci. 2013;9:361-9.

33. Guo DH, Zhang Y, Fu X, Gao Y, Liu YT, Qiu JH, et al. Complete mitochondrial genomes of Dermacentor silvarum and comparative analyses with another hard tick Dermacentor nitens. Exp Parasitol. 2016;169:22-7.

34. Liu ZQ, Liu YF, Kuermanali N, Wang DF, Chen SJ, Guo HL, et al. Sequencing of complete mitochondrial genomes confirms synonymization of Hyalomma asiaticum asiaticum and kozlovi, and advances phylogenetic hypotheses for the Ixodidae. PLoS One. 2018;13:e0197524.

35. Yu ZJ, Zhang SQ, Wang TH, Yang XL, Wang H, Liu JZ. The mitochondrial genome and phylogenetic analysis of the tick Dermacentor everestianus Hirst, 1926 (Acari: Ixodidae). Syst Appl Acarol. 2018;23:1313-21.

36. Williams-Newkirk AJ, Burroughs M, Changayil SS, Dasch GA. The mitochondrial genome of the lone star tick (Amblyomma americanum). Ticks Tick Borne Dis. 2015;6:793-801.

37. Shao R, Barker SC, Mitani H, Aoki Y, Fukunaga M. Evolution of duplicate control regions in the mitochondrial genomes of metazoa: a case study with australasian ixodes ticks. Mol Biol Evol. 2005;22:620-9.

38. Chang QC, Fu X, Song CL, Liu HB, Sun Y, Jia N, et al. The complete mitochondrial genome of Haemaphysalis concinna (ixodida: ixodidae). Mitochondrial DNA B. 2018;3:348-9.
39. Montagna M, Sassera D, Griggio F, Epis S, Bandi C, Gissi CJ. Tick-box for 3 '-end formation of mitochondrial transcripts in Ixodida, basal Chelicerates and Drosophila. PLoS One. 2012;7:e47538.

40. Sui S, Yang Y, Fang ZQ, Wang JC, Wang J, Fu YQ, et al. Complete mitochondrial genome and phylogenetic analysis of Ixodes persulcatus (taiga tick). Mitochondrial DNA B. 2017;2:3-4.

41. Shao R, Aoki Y, Mitani H, Tabuchi N, Barker SC, Fukunaga M. The mitochondrial genomes of soft ticks have an arrangement of genes that has remained unchanged for over 400 million years. Insect Mol Biol. 2004;13:219-24.

42. Mitani $H$, Talbert A, Fukunaga M. New World relapsing fever Borrelia found in Ornithodoros porcinus ticks in central Tanzania. Microbiol Immunol. 2013;48:501-5.

43. Fukunaga M, Ushijima Y, Aoki Y, Talbert A. Detection of Borrelia duttonii, a tick-borne relapsing fever agent in central Tanzania, within ticks by flagellin gene-based nested polymerase chain reaction. Vector Borne Zoonot. 2001;1:331-8.

44. Mans BJ, Klerk D, Pienaar R, Castro MH, Latif AA. The mitochondrial genomes of Nuttalliella namaqua (Ixodoidea: Nuttalliellidae) and Argas africolumbae (Ixodoidae: Argasidae): estimation of divergence dates for the major tick lineages and reconstruction of ancestral blood-feeding characters. PLoS One. 2012;7:e49461.

45. Mans BJ, Klerk D, Pienaar R, Castro MH, Latif AA. Next-generation sequencing as means to retrieve tick systematic markers, with the focus on Nuttalliella namaqua (Ixodoidea: Nuttalliellidae). Ticks Tick Borne Dis. 2015;6:450-62.

46. Boore JL, Brown WM. Mitochondrial genomes of Galathealinum, Helobdella, and Platynereis: SEQUENCE and gene arrangement comparisons indicate that Pogonophora is not a phylum and Annelida and Arthropoda are not sister taxa. Mol Biol Evol. 2000;17:87-106.

47. Cameron SL, Beckenbach AT, Dowton M, Whiting MF. Evidence from mitochondrial genomics on inter-ordinal relationships in insects. Arthropod Syst Phylo. 2006;64:27-34.

48. Cameron SL, Johnson KP, Whiting MF. The mitochondrial genome of the screamer louse Bothriometopus (Phthiraptera: Ischnocera): effects of extensive gene rearrangements on the evolution of the genome. J Mol Evol. 2007:65:589-604.

49. Salvato P, Simonato M, Battisti A, Negrisolo E. The complete mitochondrial genome of the bag-shelter moth Ochrogaster lunifer (Lepidoptera, Notodontidae). BMC Genomics. 2008;9:331.

50. Hua J, Li M, Dong PZ, Cui Y, Bu WJ. Comparative and phylogenomic studies on the mitochondrial genomes of Pentatomomorpha (Insecta: Hemiptera: Heteroptera). BMC Genomics. 2008;9:610.

51. Li H, Liu HY, Song F, Shi AM, Zhou XG, Cai WZ. Comparative mitogenomic analysis of damsel bugs representing three tribes in the family Nabidae (Insecta: Hemiptera). PLoS ONE. 2012;7:e45925.

52. Yuan ML, Zhang QL, Guo ZL, Wang J, Shen YY. Comparative mitogenomic analysis of the superfamily Pentatomoidea (Insecta: Hemiptera: Heteroptera) and phylogenetic implications. BMC Genomics. 2015; 16:460.

53. Zhang YK, Zhang XY, Liu JZ. Ticks (Acari: Ixodoidea) in China: geographical distribution, host diversity, and specificity. Arch Insect Biochem. 2019. https://doi.org/10.1002/arch.21544.

54. Hassanin A, Nelly L, Deutsch J. Evidence for multiple reversals of asymmetric mutational constraints during the evolution of the mitochondrial genome of metazoa, and consequences for phylogenetic inferences. Syst Biol. 2005;54:277-98.

55. Kilpert F, Podsiadlowski L. The complete mitochondrial genome of the common sea slater, Ligia oceanica (Crustacea, Isopoda) bears a novel gene order and unusual control region features. BMC Genomics. 2006;7:241.

56. Boore JL. Survey and summary animal mitochondrial genomes. Nucleic Acids Res. 1999;27:1767-80.

57. Xin ZZ, Liu Y, Zhang DZ, Wang ZF, Liu QN. Comparative mitochondrial genome analysis of Spilarctia subcarnea and other noctuid insects. Int J Biol Macromol. 2018;107:121-8.

58. Weigl S, Testini G, Parisi A, Dantas-Torres F, Traversa D, Colwell DD, et al. The mitochondrial genome of the common cattle grub, Hypoderma lineatum. Med Vet Entomol. 2010;24:329-35. 
59. Behura SK, Lobo NF, Haas B, Debruyn B, Lovin DD, Shumway MF, et al. Complete sequences of mitochondria genomes of Aedes aegypti and Culex quinquefasciatus and comparative analysis of mitochondrial DNA fragments inserted in the nuclear genomes. Insect Biochem Mol Biol. 2011:41:770-7.

60. Sorokina SY, Andrianov BV, Mitrofanov VG. Complete mitochondrial genome sequence of Drosophila littoralis (Diptera: Drosophilidae). Comparative analysis of mitochondrial genomes in the Drosophila virilis group. Moscow Univ Biol Sci Bull. 2010;65:224-6.

61. Clary DO, Wolstenholme DR. The mitochondrial DNA molecule of Drosophila yakuba: nucleotide sequence, gene organization, and genetic code. J Mol Evol. 1985;22:252-71.

62. Ojala D, Montoya J, Attardi G. tRNA punctuation model of RNA processing in human mitochondria. Nature. 1981;290:470-4.

63. Yokobori SI, Pääbo S. Polyadenylation creates the discriminator nucleotide of chicken mitochondrial tRNA ${ }^{\text {Tyr }}$. J Mol Biol. 1997;265:95-9.

64. Zhang M, Nie XP, Cao TW, Wang JP, Li T, Zhang XN, et al. The complete mitochondrial genome of the butterfly Apatura metis (Lepidoptera: Nymphalidae). Mol Biol Rep. 2012;39:6529-36.

65. Fang Y, Liang AP. The complete mitochondrial genome of Ugyops sp. (Hemiptera: Delphacidae). J Insect Sci. 2018;18:1-13.

66. Wang Y, Cao JJ, Li WH. Complete mitochondrial genome of Suwallia teleckojensis (Plecoptera: Chloroperlidae) and implications for the higher phylogeny of stoneflies. Int J Mol Sci. 2018;19:680

67. Hanada T, Suzuki T, Watanabe K. Translation activity of mitochondrial tRNA with unusual secondary structure. Nucleic Acids Symp Ser. 2000:44:249-50

68. Bae JS, Kim I, Sohn HD, Jin BR. The mitochondrial genome of the firefly, Pyrocoelia rufa: complete DNA sequence, genome organization, and phylogenetic analysis with other insects. Mol Phylogenet Evol. 2004:32:978-85.

69. Jühling F, Pütz J, Bernt M, Donath A, Middendorf M, Florentz C, et al. Improved systematic tRNA gene annotation allows new insights into the evolution of mitochondrial tRNA structures and into the mechanisms of mitochondrial genome rearrangements. Nucleic Acids Res. 2012:40:2833-45.

70. Breinholt JW, Kawahara AY. Phylotranscriptomics: saturated third codon positions radically influence the estimation of trees based on next-gen data. Genome Biol Evol. 2013;5:2082-92.

71. Watanabe YI, Kawai G, Yokogawa T, Hayashi N, Kumazawa Y, Ueda T, et al. Higher-order structure of bovine mitochondrial tRNA (SerUGA): chemical modification and computer modeling. Nucleic Acids Res. 1994;22:5378-84

72. Araya-Anchetta A, Busch JD, Scoles GA, Wagner DM. Thirty years of tick population genetics: a comprehensive review. Infect Genet Evol. 2015:29:164-79.

73. Mixson TR, Lydy SL, Dasch GA, Real LA. Inferring the population structure and demographic history of the tick, Amblyomma americanum Linnaeus. J Vector Ecol. 2006;31:181-92.

74. Shao R, Barker SC, Mitani H, Takahashi M, Fukunaga M. Molecular mechanisms for the variation of mitochondrial gene content and gene arrangement among chigger mites of the genus Leptotrombidium (Acari: Acariformes). J Mol Evol. 2006;63:251-61.

75. Boore JL. Big trees from little genomes: mitochondrial gene order as a phylogenetic tool. Curr Opin Genet Dev. 1998;8:668-74.

76. Dowton M, Austin AD. Evolutionary dynamics of a mitochondrial rearrangement "hot spot" in the Hymenoptera. Mol Biol Evol. 1999;16:298-309.

77. Dowton M, Castro LR, Austin AD. Mitochondrial gene rearrangements as phylogenetic characters in the invertebrates: the examination of genome 'morphology'. Invertebr Syst. 2002;16:345-56.

78. Cameron SL, Sullivan J, Song H, Miller KB, Whiting MF. Amitochondrial genome phylogeny of the Neuropterida (lace-wings, alderfliesand snakeflies) and their relationship to the other holometabolous insect orders. Zool Scr. 2009;38:575-90.

79. Xu W, Jameson D, Tang B, Higgs PG. The relationship between the rate of molecular evolution and the rate of genome rearrangement in animal mitochondrial genomes. J Mol Evol. 2006;63:375-92.

80. Beckenbach AT. Mitochondrial genome sequences of Nematocera (lower Diptera): evidence of rearrangement following a complete genome duplication in a winter crane fly. Genome Biol Evol. 2012;4:89-101.

81. Cameron SL, Whiting MF. The complete mitochondrial genome of the tobacco hornworm, Manduca sexta, (Insecta: Lepidoptera: Sphingidae), and an examination of mitochondrial gene variability within butterflies and moths. Gene. 2008;408:112-23.

82. Mccooke JK, Guerrero FD, Barrero RA, Black M, Hunter A, Bell C, et al. The mitochondrial genome of a Texas outbreak strain of the cattle tick, Rhipicephalus (Boophilus) microplus, derived from whole genome sequencing pacific biosciences and Illumina reads. Gene. 2015;571:135-41.

83. Nguyen LT, Schmidt HA, von Haeseler A, Minh BQ. IQ-TREE: a fast and effective stochastic algorithm for estimating maximum likelihood phylogenies. Mol Biol Evol. 2015;32:268-74.

84. Tamura K, Stecher G, Peterson D, Filipski A, Kumar S. MEGA6: molecular evolutionary genetics analysis version 6.0. Mol Biol Evol. 2013;30:2725-9.

85. Minh BQ, Nguyen MAT, von Haeseler A. Ultrafast approximation for phylogenetic bootstrap. Mol Biol Evol. 2013;30:1188-95.

86. Caterino MS, Reed RD, Kuo MM, et al. A partitioned likelihood analysis of swallowtail butterfly phylogeny (Lepidoptera: Papilionidae). Syst Biol. 2001;50:106-27.

87. Megens HJ. Molecular phylogeny of the oriental butterfly genus Arhopala (Lycaenidae, Theclinae) inferred from mitochondrial and nuclear genes. Syst Entomol. 2004;29:115-31.

88. Castro LR, Dowton M. Mitochondrial genomes in the Hymenoptera and their utility as phylogenetic markers. Syst Entomol. 2007;32:60-9.

89. Drummond AJ, Rambaut A. BEAST: Bayesian evolutionary analysis by sampling trees. BMC Evol Biol. 2007;7:e214.

90. Shi QH, Sun XY, Wang YL, Hao JS, Yang Q. Morphological characters are compatible with mitogenomic data in resolving the phylogeny of nymphalid butterflies (Lepidoptera: Papilionoidea: Nymphalidae). PLoS ONE. 2015;10:e0124349.

91. Klompen JSH, Oliver JH. Systematic relationships in the soft ticks (Acari: Ixodida: Argasidae). Syst Entomol. 1993;18:313-31.

92. Mans BJ, De Castro MH, Pienaar R, De Klerk D, Gaven P, Genu S, et al. Ancestral reconstruction of tick lineages. Ticks Tick Borne Dis. 2016;7:509-35.

93. Shao R, Barker SC. Mitochondrial genomes of parasitic arthropods: implications for studies of population genetics and evolution. Parasitology. 2007;134:153-67.

94. Cameron SL. How to sequence and annotate insect mitochondrial genomes for systematic and comparative genomics research. Syst Entomol. 2014;39:400-11.

95. Sheffield NC, Song H, Cameron SL, Whiting MF. Nonstationary evolution and compositional heterogeneity in beetle mitochondrial phylogenomics. Syst Biol. 2009;58:381-94.

96. Detmer SA, Chan DC. Functions and dysfunctions of dynamics. Nat Rev Mol Cell Bio. 2007;8:870-9.

97. Levin DB, Danks HV, Barber SA. Variations in mitochondrial DNA and gene transcription in freezing-tolerant larvae of Eurosta solidaginis (Diptera: Tephritidae) and Gynaephora groenlandica (Lepidoptera: Lymantriidae). Insect Mol Biol. 2010;12:281-9.

98. Jain S, Al-Hasan Y, Thompson L. 231: prenatal hypoxia programs increased hepatic mitochondrial gene expression in guinea pig (GP) offspring. Am J Obstet Gynecol. 2013;208:S106

99. Zhang JY, Lu BE, Yu DN, Zhang LP, Al-Attar R, Storey KB. The complete mitochondrial genome of Dryophytes versicolor: phylogenetic relationship among hylidae and mitochondrial protein-coding gene expression in response to freezing and anoxia. Int J Biol Macromol. 2019;132:461-9.

100. Wang TH, Zhang SQ, Pei TW, Yu ZJ, Liu JZ. The complete mitochondrial genome and expression profile of mitochondrial protein-coding genes in the bisexual and parthenogenetic Haemaphysalis longicornis. Front Physiol. 2019;10:982.

101. Ballard JWO, Pichaud N. Mitochondrial DNA: more than an evolutionary bystander. Funct Ecol. 2014;28:218-31.

102. Beckenbach AT, Joy JB. Evolution of the mitochondrial genomes of gall midges (Diptera: Cecidomyiidae): rearrangement and severe truncation of tRNA genes. Genome Biol Evol. 2009;1:278-87.

103. Jewess PJ. Insecticides and acaricides which act at the rotenonebinding site of mitochondrial NADH: ubiquinone oxidoreductase; 
competitive displacement studies using a $3 \mathrm{H}$-labelled rotenone analogue. Biochem Soc T. 1994;22:247-51.

104. Motoba K, Suzuki T, Uchida M. Effect of a new acaricide, fenpyroximate, on energy metabolism and mitochondrial morphology in adult female Tetranychus urticae (two-spotted spider mite). Pestic Biochem Phys. 1992;43:37-44.

\section{Publisher's Note}

Springer Nature remains neutral with regard to jurisdictional claims in published maps and institutional affiliations.
Ready to submit your research? Choose BMC and benefit from:

- fast, convenient online submission

- thorough peer review by experienced researchers in your field

- rapid publication on acceptance

- support for research data, including large and complex data types

- gold Open Access which fosters wider collaboration and increased citations

- maximum visibility for your research: over 100M website views per year

At BMC, research is always in progress.

Learn more biomedcentral.com/submissions 